\title{
Negotiating the emotions of change: Research, restructuring and the doctoral student
}

\section{Herman}

Department of Education, Management, Law and Policy Studies

University of Pretoria

South Africa.

e-mail: Chaya.herman@up.ac.za

\begin{abstract}
This article is a reflective account of the emotions generated by the research journey, and the challenges these pose for doctoral students, particularly when researching organisations and topics close to their interests and background. By reflecting on my experience, and engaging with the literature to explore other novice researchers' reflective accounts of their research journey, I identify a host of emotions that are generated by the ideological, political and methodological facets of the research. I argue that doctoral students are ill-prepared to deal with the emotions of their research and are often attempted to ignore or control these emotions. This reduces the researchers' ability to engage fully with the process, it limits the data that could be collected, and results in unresolved emotional dilemmas. The article proposes that doctoral students may be better prepared to manage their emotions if they would be exposed to researchers' accounts (such as this one) on the role of emotions in research.
\end{abstract}

\section{INTRODUCTION}

A recent body of research points to the significance of the part played by emotions in the research process. Those who took the reflexive turn in social sciences (see Ribbens and Edwards 1998; Alversson and Skoldberg 2000; Denzin and Lincoln 2002) tend to locate the researcher emotionally and autobiographically in relation to his/her research work. It is now widely acknowledged that the researcher's values, feelings, culture and history shape and defines the inquiry, and that research is often a personal matter (Wilkins 1993). This is even more so when research is undertaken by doctoral students, since it involves the students' personal development and is sometimes motivated by the students' need to take stock and make sense of their life and experiences so far (Reason and Marshall 1987; Boucher and Smyth 2004). 
Despite these developments, doctoral studies tend to emphasise the rational and technical competencies of producing research and neglect the emotional aspects of learning. In fact, the role of emotions is mostly ignored in the standard literature on researchmethodology (See for exampleSilverman 2005; Cohen, Manion and Morrison 2000; Bell 1993). There is an implicit expectation that the researchers would separate between, what Peshkin (1984) describes, the two general categories of selves that they bring into the field: the human-participant and the research-participant. Some researchers explain this approach by referring to what Hochschild (1983) describes as 'feeling rules' - that is, how we are supposed to feel in different situations, and 'display rules' - how we are supposed to express our feelings (Kleinman and Copp 1993; Young and Lee 1996). As members of a research fraternity, researchers share a culture dominated by systematic methodology and the ideology of professionalism. In this ideology emotions are suspect as they are assumed to contaminate research by impeding objectivity. Consequently, researchers try to control their emotions by wearing a mask of objectivity. Even those who abandoned this positivist goal of objectivity still argue that researchers need to maintain 'social distance' from the case to allow analytical work to be accomplished (Gilbert 2001, 18).

A growing body of literature challenges the polarisation between the rational and emotional in the research journey. There is a view that denying the emotions of research means also ignoring the relation between emotions and reason, in other words, the emotional nature of learning. McLaughlin (2003) maintains that the research process is deeply entwined with feelings and perceptual processes. Therefore the researcher's self-understanding and self-reflection would strengthen the research. Feelings should be used as data, thus teasing out the researcher's assumptions that are taken for granted (Kleinman and Copp 1993, Cylwick 2001).

Researchers seldom admit to their emotions; therefore the accumulated body of knowledge about it is meagre and inadequate. Moreover, researchers tend to underreport their negative feelings and to over-report their good feelings and enjoyment of the fieldwork (Van Maanen et al. 1993). This reflective account of my doctoral research journey enters the terrain of the debate by identifying a host of emotions that were generated during the various stages of the research and demonstrate the impact they had on the process, the research participants and myself. Though I am aware of the distinction some scholars make between feelings and emotions (Damasio 1999; Solomon 2003) for the purpose of this article these terms will be used interchangeably. 


\section{THE DOCTORAL RESEARCH JOURNEY}

The issues discussed in this article emerged during my own experience as a doctoral student, researching a controversial process of restructuring in the Jewish community schools in Johannesburg. The schools were under the auspices of the South African Jewish Board of Education (the Board), with which I was associated for two decades (Herman 2004). I was investigating the restructuring in real time as it evolved in order to explain why it happened, how, with what impact and how the different stakeholders understood and experienced this process of change. The composition of this qualitative case study relied heavily on interviews with various stakeholder groups (namely, teachers, parents, managers, lay leaders of the schools and community leaders) observations (participant and non-participant), document analysis and informal conversations with members of the community.

The research spanned three-and-a-half years, two of which were dedicated to fieldwork. During this time I was immersed in the study as both an insider (community member as well as a professional officer at the Board) and outsider (researcher) to the change process. As a result I was thrown into a maelstrom of emotions: those of the participants' (Marshak 1984) as well as my own.

As a doctoral student and a new member of the research fraternity, I was desperately trying to prove that I could separate the emotional and personal from the professional. In hindsight, as the following sections will clearly demonstrate, this was a pointless attempt that impeded my research. In what follows, I first set the context of my doctoral studies and discuss my position as both insider and outsider to the case and the emotions it induced. Second, I identify the range of emotions that have impacted on and shaped my choices around the research processes. And lastly, I discuss how, as a novice researcher, I dealt (or rather did not deal) with these emotions and contrast it with the way in which other researchers manage their emotions in similar circumstances.

The article demonstrates that the attempt to ignore or separate one's emotions from the research process may reduce the researcher's ability to engage with the process and limit the data that could be collected. It proposes that researchers' emotions need to be acknowledged and managed throughout the research process, not only to provide them with emotional relief but also to encourage self-understanding, making researchers aware of how their emotions influence the research process.

\section{The context of the research and its emotions}

The restructuring at the Jewish schools took place during the first few years of the new millennium as a result of financial and leadership crises. Initially the process was 
perceived as a managerial restructuring that aimed at reducing debts by introducing market-based practices, such as efficiency, decentralisation and accountability, into the management of the community schools. However, as the process unfolded, it became apparent that the managerial restructuring was masking a religious restructuring whereby the secular/traditional majority was losing its dominance to the ultra-Orthodox minority

The restructuring created much turmoil in the community, especially as selected lay leaders, with the support of the Chief Rabbi and the community's financial elite, secretly appointed a new chief executive officer (CEO) and gave him a free hand to manage the schools and to replace the professional officers of the Board. Suspicions grew since the CEO himself was an ultra-Orthodox Jew and his remuneration was directly linked to the debt reduction achieved. Feelings of betrayal and doubt polarised the school community and ignited heated debates as stakeholders positioned themselves on opposite sides of the process.

The process of the change itself was experienced by the school community as too broad, autocratic and incoherent. During the interviews my respondents exhibited various emotions, mostly negative, such as denial ('nothing really changed'), fear of the future and despondent dependency ('it could be worse if the CEO left'), defeat and disempowerment ('what can I do?'), isolation and withdrawal ('who can you talk to?'), and division and suspicion ('they are all looking after themselves').

This emotional process of change was coupled with the insecurities experiences by the Jewish community as a result of shifting local, national and global conditions. Locally, a profound despondency had overtaken the once fairly privileged community due to emigration, crime and economic hardship. Internationally, certain events and processes, such as the second Intifada in the Middle East, the rise of antiSemitism world-wide and the South African government's pro-Palestinian stance further intensified feelings of insecurity and frustration in the South African Jewish community at the time of the restructuring of its schools.

It is obvious that the restructuring of the Jewish community schools produced strong emotions in my research respondents and that it was not possible for any Jewish researcher (like myself) to observe the process from a position of detachment. Various emotions were generated by my dual position as both insider and outsider to the research.

\section{The emotions of the researcher as insider (community member)}

The research affected me personally, ideologically and professionally; each level inducing myriad emotions. My retrenchment at the early stage of the restructuring process presented me with both losses and opportunities. On the one hand, it provided 
me with a research topic worth pursuing, and the opportunity to focus on my doctoral studies which I had begun a year earlier. On the other hand, I experienced the loss of community, position and income. Furthermore, as an educationalist who has been socialised in the discourse of 'teachers as professionals' and who has been adversely affected by the managerialist reform, I found it difficult to applaud the top-down managerial process of change.

The religious aspect of the restructuring carried intense emotions for the respondents who were aware of it, and especially for me. As a traditional/secular Jew with common liberal views, I was deeply disturbed when I observed the permeation of certain ultra-Orthodox practices into the schools, such as when girls over 12 were not allowed to perform on stage, or when sex education was curtailed. I could not follow Peshkin's (1988) advice to separate my private-self from my researchself: what happened to the schools was happening to me, my family, colleagues and friends. My annoyance with certain processes was accompanied with shame, concern and immense sadness.

\section{The emotions of the researcher as an outsider (academic)}

The doctoral studies presented me with theoretical and conceptual challenges unparallel to any other learning experience. I had to transform from being a practitioner to becoming a researcher. I struggled to grasp the complexities of the research journey (Jansen, Herman and Pillay 2004), such as finding a focus, formulating the research questions, critically engaging with the literature, finding a conceptual framework and mastering the competencies which are required for conducting research. The focus on anxieties involved with the technical competence of the research learning rather than on emotions generated by the case itself, has some advantages. This view is articulated by Hockey (1996). As an ex-soldier Hockey encountered an avalanche of emotions as he researched military experiences. He maintained that the focus on the ability to conduct research helped him to disguise the emotional baggage he carried from his military experience.

My position as insider-outsider also produced frustration and guilt as I had to experience what Labaree (2003) identifies as transformation from the normative culture of the teaching profession and its effort to produce valued outcomes, to the analytical perspective of the research and its effort to produce a valid explanation of an educational phenomenon. I had to fight my urge to intervene and resist the process in order not to jeopardise the integrity of my research. I was concerned that if I let know of what I have discovered or disclose my views and emotions, this may block my access to certain stakeholders and information and could lead the interviews in a particular way. 
As both insider and outsider I had difficulty clarifying my role to the members of the community whom I observed at different meetings, and probably also to myself. The CEO was reluctant to allow me an access as an academic (outsider), but could not deny me an access as a parent and community member (insider). Subsequently I was very hesitant when I requested interviews and sometimes had to wait a few days before I gathered enough courage to approach certain stakeholders, especially those who support the new management. As I became more confident in my role as a researcher, I followed the CEO to every public meeting and openly took minutes of the proceedings. I was never refused entry but always felt as an uninvited guest.

\section{Emotions generated by the fieldwork}

The emotional investment in the study acted as a positive force that motivated and sustained me throughout the research journey. Most of my respondents were also deeply involved in the restructuring process and used the space provided by the interviews or informal conversations to reconstruct their experiences and deal with their emotions. This benefited the study as I had eager-to-talk respondents. Some interviewees even found it therapeutic to speak to a researcher who seldom interrupted them and assured confidentiality and anonymity. The following excerpts from interviews demonstrate this point:

Manager: But he [the CEO] didn't acknowledge me in any way - nothing.

Researcher: How does that make you feel?

Manager: Angry. I do feel angry.

Researcher: Yes.

Manager: It's nice to talk about it - there's nobody to talk to about it .... It's lonely and you're isolated and there isn't really anybody to share anything with.

Parent: That's why I quite enjoy ... talking to you. [This is] not a conversation I can have with just anybody. You know, it's not something everybody can relate to - I will lose them somewhere along [the way] ... .

There is an increasing demand on the researchers to attend to the emotional needs of their respondents. Female researchers in particular stress the researchers' responsibility to care for their respondents and to use the interview as a therapeutic opportunity (Mauthner, Birch, Jessop and Miller 2002; DeMarrais and Tisdale 2002; Birch and Miller 2000; Owen 1996; Finch 1984). My role as a 'therapist' generated mixed feelings mostly because I was not always a willing therapist. While listening and recording my respondents' experiences I harboured various feelings towards them, especially towards those informants whose values and perceptions clashed with mine. At times I felt anger at those stakeholders who seemed to comply with the 
restructuring in order not to jeopardise their personal advancement; I felt boredom ('I heard this story before'), self-doubt ('How am I managing the interview? Am I probing enough? Am I biased?'), depression, frustration, irritation ('Don't they see what is going on?') and sometimes pity or sadness as I realised that many of my respondents are trapped in a 'Catch-22' situation. I did not articulate these feelings to my respondents, and even to me they were not always clear. Like Wincup (2001) I was reluctant to be honest about negative feelings toward my interviewees. According to the researcher's 'display rule' I felt that I should act as if I empathised with the participants and agreed with their interpretations, or at least refrain from displaying disagreement. My research therefore involved 'emotional labour' (Hochschild 1983): not only acting out feelings such as surprise and confusion, but also hiding my own emotions and producing the necessary feeling that would encourage respondents to reveal their inner thoughts and trust me.

In hindsight, the denial or suppression of emotions created an unauthentic interview situation that limited the data I was able to collect. It was also energy depleting and detrimental to my health - as manifested by my severe headaches and sleepless nights during the research journey. A fitting example is the following extract from an interview, whereby a lay leader who was involved in bringing in the CEO and dismissing the previous management, articulated his discomfort to speak to me about the process. Instead of acknowledging my discomfort and maybe using this moment of truth to start a real dialogue, I chose to pretend that I was unemotional about the process. Consequently, I missed an opportunity to engage in meaningful dialogue about the previous management:

Lay leader: Yes. And he [the previous director] didn't address the running of the system.

Researcher: What do you mean by that?

Lay leader: The Board itself was - I'm getting into sensitive territory. You were affected.

Researcher: Personally I'm very happy, so you don't have to worry about that (laugh).

Lay leader: I mean the Board was top heavy in the structure. The schools were also top heavy .... .

Kleinman and Copp (1993) rightly argue that researchers who ignore their negative feelings cannot use them to generate questions about the process. Gordon (1987) similarly discovered that arguing with interviewees aided the research. He suggests that expressing disagreement and saying what one thinks can be an engaging experience, constituting closeness rather than distance. 
It was easier for me to feel a strong bond with interviewees who experienced the restructuring in a similar way to me. However, as I was emotionally attuned with them I was not always able to pick up disconfirming evidence. I also believe that in some cases I transferred my feelings into the interview; a process referred to by psychotherapists as counter-transference. These slips and missed opportunities became apparent during the data analysis phase. For example, many respondents argued that 'nothing ha[d] changed' in the schools. I viewed this response as their defence mechanism or as an attempt to delude me, and thus I did not take cognisance of what they were really saying. It was only later that I realised that some community members were not aware of the ideological transformation that was so obvious to me. This prompted me to look for other explanations for their perceptions, such as hegemony. I therefore concede with Delagado-Gaitan (1993) that sharing the same background as the participants does not necessarily means that the researcher is more inform about participants' feelings, values and practices.

An additional emotional source was my niggling feeling of guilt that I was taking advantage of my participants' distressing experiences to generate data for my research and that this made me a 'spy' in my community. Admittedly, I used my connections with community members to facilitate access to information and, as a result, have struggled with the notion of deception. A number of researchers (Peshkin 1984; Griffiths 1998) are of the view that fieldwork is always associated with deception. The punishment for this deception, Peshkin correctly concedes, is self-inflicted guilt and anxiety that accompany researchers' consciousness as they strip off their mask.

The observations, whether as a non participant or participant, were a distressful experience for me. I observed numerous annual general meetings (AGM) and parentteacher association (PTA) meetings, conferences, and public and private meetings, either as an employee, a parent or a researcher. As I became more knowledgeable of the restructuring process and the 'behind the scene' micropolitics, I often wanted to shout out at meetings that the information speakers were giving was simply a manipulation of the facts. On one occasion I could not tell a friend that a lay leader was deceiving her. I was often frustrated by my self-imposed silence, especially when I realised that by the time my findings would appear most of the processes would be completed, and most of those in charge would have achieved their immediate goals. A similar feeling of frustration was experienced by Hodkinson and Sparkes (1993), more so when they realised that withholding important information from stakeholders contradicted their claim of empowering the participants.

During the advanced stage of the research - after the first data analysis phase and with my growing understanding of the process - I began to understand my personal loss as part of the community's shift to the 'right', became more confident as a 
researcher and more aware of my emotions. My interviews then became a dialogue between equals, negotiating meanings and testing hypotheses. It was at this stage that I experienced real learning and profound growth: the mask had been taken off and I was able to become a whole person again - the human and the research practitioner became one, an emotional and rational human being.

\section{Emotions of data analysis}

Some of the emotions that I had attempted to control during the interviews resurfaced in the data analysis phase. Since this phase involved shifting of attitudes and values, it was often loaded with emotions generated by new learning and new understandings. Arlie Hochschild $(1998,6)$ makes this point when she argues that emotions emerge as a result of a newly grasped reality as it clashes with the template of prior expectation. McLaughlin (2003) adds that it is vital for researchers at this stage to be aware of their emotions in order to fight the temptation to alter or ignore data that challenges their understanding of the process.

I meticulously coded line-by-line 1700 pages of interviews, 150 pages of my research journal and three arch-lever files of documents using Atlas.ti (computerassisted qualitative data analysis software). Reading and analysing my research diary made me aware of my emotions, hopes and fears - as well as my struggles to control them. Halfway through the decoding process I began to notice the synergies between the managerial and the ideological/religious restructuring, thus forming the conceptual framework of the study, and I had to recode all the text again. This rather mechanical task provided me with some emotional distance from the field and allowed me to put a semblance of order to my thoughts and emotions. Barr (1998), in her reflection on this stage of the research, similarly described how she read, reread, coded and recoded her transcripts 'until the anger and the pain began to subside and [she] began to see some patterns emerging' $(1998,99)$.

The analysis process itself was a lone pursuit, imbued with feelings of missed opportunities as well as the excitement of new insights. As I read through the transcripts I realise, like Kanuha (2000), that there were many examples where I overlooked some information along with many taken-for-granted assumptions. I became aware of the many moments when I did not allow my respondents to complete sentences or thoughts because I thought that I knew what they are referring to. I realised that my perception is one perspective of the situation along other ways of seeing. I began to voice my own emerging political, ideological and epistemological stances. I spent hours searching the internet and the libraries for literature that would help me make sense of my new reality. I neglected all my other 'normal' social obligations as mother, wife, daughter and friend - but felt no guilt. I was completely self-absorbed 
and incapable of focusing on anything other than my own learning and the emotions it generated.

\section{The emotions of writing}

The writing phase provided me with the first opportunity to let go of my emotions, yet it produced its own set of feelings. At the beginning, the huge volume of material that I had obsessively collected and coded overwhelmed me - I was stuck. How was I going to reduce this mountain of information into 400 pages of coherent text? Which data should I include and which information should I leave out? I had difficulty cutting out some data that I thought was important but which disclosed the identity of the interviewees. I occasionally felt that I deliberately wanted to give away the identity of some respondents and to use the knowledge I had gained to settle some scores; to show the manipulation and deception. At the same time I had to remind myself constantly of my role as a researcher and of my commitment to ensure confidentiality and anonymity.

I began by writing a personal story of my experience and understanding of the restructuring process. I ignored the theoretical framework and just 'poured' it all out. In a way I was an interviewee putting on article my side of the story. The result was a 100-page emotional, non-academic manuscript that had great therapeutic value for me. This manuscript was then put aside and I began to reconstruct another text in which I was able to bring the different perceptions and experiences together. Occasionally, my personal story filtered through and my writing slipped from the social to the personal and emotional. Depersonalising the text was a long and difficult process that required repeated editing in order to detach myself from the data, to let go of emotions and to view the process from a social and theoretical perspective. My supervisors' input in this progression was vital as they constantly made me aware of examples where my emotions took over my academic writing.

\section{The emotions of wrapping-up}

After I completed the last line of my dissertation, I cried: my sense of relief and achievement were tinged with sadness and emptiness. My doctoral supervisor compares this period to antenatal depression experienced by some new mothers.

An added unexpected emotion was a feeling of alienation from my community. Since the research questioned the Jewish community's ethos and narrative, I had lost my innocence and the uncritical manner in which I had viewed my surroundings, and became aware of the power relations and politics within the community. Carter and Delamont (1993) are right when they argue that fieldwork in any setting 
where either the researcher or the respondent is emotionally engaged, changes the researcher forever. Bauman (2001) maintains that the biblical story of Adam and Eve describes a similar phenomenon. Adam and Eve's penalty for eating from the tree of knowledge was their banishment from the safety of the Garden of Eden, from paradise. A community (real or imagined) provides a sense of paradise and is a safe haven for those who accept and submit to its narrative. In another context, Peshkin (1984) also reports the feelings of estrangement and alienation from the field study, of being 'the odd man out'. For me, the feeling of estrangement from the field study meant alienation from my community. This also brought tensions into my home as my family did not go through the same process of transformation. While they on the whole supported me, they also wanted me to tone down some of my criticism as to not jeopardise their position in the community. It seems that researching one's own community should come with a warning: do so at your peril!

Interestingly, while I felt like the 'odd woman out', certain stakeholders did not perceive me as such. As mentioned before, during the study I became a confidant and a sounding board for many school members who eagerly unburdened themselves in the space provided by the research. As a result, by the end of the process I was emotionally exhausted and even resentful. I constantly had to remind myself that I had volunteered to take on this role for my own ambitions - to understand a process that could have an irrevocable impact on the community and to obtain a degree (doctorate). This posed another ethical and emotional predicament: was it fair for me to stop being a sounding board once my fieldwork was complete and I no longer required the information? When I eventually detached myself from my respondents I felt guilty at having abandoned them.

It seems that exiting fieldwork is an emotional endeavour seldom mentioned in the research literature. Williamson $(1996,30)$ makes this point when he argues that 'despite the wisdom of research methods textbooks, it is often much harder to get out of the door than to get into it in the first place'.

\section{The emotions of publication}

The dissemination of data and publication of the study generated conflicting feelings. I struggled with a perennial problem affecting Jewish researchers: that is, the extent to which we would like to expose the 'inside' stories of our community to outsiders, especially as I was not indifferent to the community's feeling of isolation and depression in the new South Africa. I constantly debated whether uncovering processes in the community and disseminating the research findings would mean that I was being disloyal to the community, and whether those who have a less favourable view of the community could exploit these findings. 
Even though I have now published my dissertation in book form (Herman 2006), I am continuously wrestling with conflicting emotions. It is exhilarating seeing one's first book in print, yet there is constant uneasiness as to whether the book will have the desired impact. It seems that some emotional issues cannot be fully resolved, and that emotional turmoil is the price researchers have to pay when engaging in emotionally loaded and controversial study.

\section{REFLECTION - DEALING WITH THE EMOTIONS OF RESEARCH}

When I began my research I did not anticipate the vortex of emotions that would engulf my respondents and me, and I had no means of dealing with them. As demonstrated in this article I wasted vital energy controlling my emotions for the sake of objectivity and validity. At the same time I gained a deeper understanding of the process when I was able to acknowledge my emotions. It is evident that researchers need to manage their emotions not only in order to ease the emotional burden (which is important by itself) but also in order to explore who they are and what they believe or feel when they undertake research. It is evident that without this self-understanding researchers might not see how they shape the story.

In my postdoctoral studies I reflected on my research journey and engaged with the literature on qualitative research in depth. It was comforting to me that other researchers, in their reflective accounts on qualitative studies, articulated similar errors of perception and lack of preparedness to deal with emotions that surfaced during the research process (see for example Kleinman 1991; Wilkins 1993; Sutton and Schurman 1998; Wincup 2001; DeMarrais and Tisdale 2002; Rager 2005; Mautnner and Doucet 2003). There is an argument that one can never prepare students for the research experience and that the only way to learn it is to actually do it (Ball 1990). In many aspects it is a rite of passage, and a high degree of understanding of the factors that impacted on the research is mostly achieved with hindsight (Mauthner and Doucet 2003). While I fully agree with these statements there are ways in which this emotional passage can be managed and supported. I do not imply that by managing emotions researchers could or should avoid the pain and ambiguities of the research process. I merely suggest that being aware of the emotions would enhance the quality of the research and facilitate the journey.

This reflective account underscores the role of writing as an emotional release. This includes the research diary, the writing of a personal account, the writing and rewriting of text as well as the writing of this reflective account. The literature suggests other means by which novice researchers manage their emotions, such as group support (Kleinman and Copp 1993; Sutton and Schurman 1998; DeMarrais 
and Tisdale 2002; Mclaughlin 2003), anticipating the emotional level of the research (Sutton and Schurman 1998), enlisting the supervisor's support (Reason and Marshall 1987; McLaughlin 2003; Boucher and Smyth 2004) or even the support of a clinical psychology (Sutton and Schurman 1998; Rager 2005).

The main problem is that doctoral students are often not aware of the emotional aspect of the research journey. Rager (2005) revealed that she did not discuss the personal or emotional impact of her research even with her sympathetic chair of the research committee because she had not encountered writing on the emotional facet of the qualitative research and she therefore felt that what was she experiencing 'was unique and best kept within [her] private circle of support'. Like Rager I perceived my emotions as a personal matter that I had to overcome alone. I therefore support her call for more 'formal safeguards' during the research process and propose that doctoral students may be better prepared to manage their emotions if they would be exposed to researchers' reflective accounts (such as this one) on the role of emotions in research.

\section{CONCLUDING REMARK}

Research learning is a complex process strewn with obstacles, anxieties and frustration as well as excitement and satisfaction. Many doctoral students never complete their journey. Perhaps the emotional price that they have to pay is just too high. This reflective account provides a glimpse into a relatively neglected, yet important, area and should be read together with other researchers' accounts. Even though each case study is unique and produces a distinctive set of emotions, there is some commonality. Further study of the emotions of research learning is needed in order to add conceptual substance to this notion, to gain a better understanding of the ways that researchers not only managing their emotions, but also integrating them into their research processes, and to provide practical suggestions to those responsible for designing and supervising doctoral studies.

\section{REFERENCES}

Alversson, M. and K. Skoldberg. 2000. Reflexive methodology. Sage Publications.

Ball, S. 1990. Self-doubt and soft data: Social and technical trajectories in ethnographic fieldwork. Qualitative Studies in Education 3 (2): 157-171.

Barr, J. 1998. Theoretical voices and women's own voices. In Feminist dilemmas in qualitative research, eds. J. Ribbens and R. Edwards, 86-102. Sage Publications.

Bauman, Z. 2001. Community: Seeking safety in an insecure world. Polity Press. 
Bell, J. 1993. Doing your research project: a guide for first-time researchers in education and social science. Second edition. Open University Press.

Birch, M. and T. Miller. 2000. Inviting intimacy: The interview as therapeutic opportunity. International Journal of Social Research Methodology 3 (3): 189-202.

Boucher, C. and A. Smyth. 2004. Up close and personal: reflections on our experience of supervising research candidates who are using personal reflective techniques. Reflective Practice 5 (3): 345-356.

Carter, K. and S. Delamont. (Eds.). 1996. Qualitative research - The emotional dimension. Averbury Publication.

Cohen, L., L. Manion and K. Morrison. 2000. Research methods in education. Fifth edition. London and New York: Routledge Falmer.

Cylwik, H. 2001. Notes from the field: Emotions of place in the production and interpretation of text. International Journal of Social Research Methodology 4 (3): 243-250.

Damasio, A. 1999. The Feeling of what happens: body and emotion in the making of consciousness. New York: Harcourt Brace.

Delagado-Gaitan, C. 1993. Researching change and changing the researcher. Harvard Educational Review 63 (7): 389-411.

DeMarrais, K. and K. Tisdale. 2002. What happens when researchers inquire into difficult emotions? Reflection on studying women's anger through qualitative interviews. Educational Psychology 37 (2): 115-123.

Denzin, K. N. and Y. S. Lincoln. 2002. The qualitative inquiry reader. Thousand Oaks, Calif.: Sage publications.

Finch, J. 1984. It's great to have someone to talk to: The ethics and politics of interviewing women. In Social researching: politics, problems, practice, eds. C. Bell and H. Roberts, 70-87. London, Routledge and Kegan Paul.

Gilbert, K. R. 2001 . The emotional nature of qualitative research. CRC Press.

Gordon, D. F. 1987. Getting close by staying distance: fieldwork with proselytising groups. Qualitative Sociology 10:267-287.

Griffiths, M. 1998. Educational research for social justice-Getting off the fence. Open University Press.

Herman, C. 2004. Prophets and profits - Managerialism, fundamentalism and the restructuring of Jewish community schools in South Africa. Ph.D. Dissertation, University of Pretoria.

-. 2006. Prophets and profits - Managerialism and the restructuring of Jewish schools in South Africa. Cape-Town: HSRC Press.

Hochschild, A. R. 1983. The managed heart, commercialisation of human feeling. Berkley University of California.

- 1998. Sociology of emotion as a way of seeing. In Emotions in social life, critical themes and contemporary issues, eds. G. Bendelow and S. J. Williams, 3-15. Routledge Publishers. 
Hockey, J. 1996. Putting down smoke: emotion and engagement in participant observation. In Qualitative research: the emotional dimension, eds. K. Carter and S. Delamont, 12-27. Avebury, Ashgate Publishing Limited.

Hodkinson, P. and A. C. Sparks. 1993. To tell or not to tell? Reflecting on ethical dilemmas in stakeholder research. Evaluation and Research in Education 7 (3): 117-129.

Jansen, J. D., C. Herman and V. Pillay. 2004. Research learning. Journal of Education 34:79102.

Kanuha, V. K. 2000. Being native versus 'going native'. Social Work 45 (5): 439-447.

Kleinman, S. 1991. Field-worker's feelings: what we feel, who we are, how we analyse. In Experiencing fieldwork, eds. W. B. Shaffir and R. A. Stebbins, 184-195. Sage Publications.

Kleinman, S. and M. A. Copp. 1993. Emotions and fieldwork. Sage publications.

Labaree, D. F. 2003. The peculiar problems of preparing educational researchers. Educational Researcher 32 (4): 13-22.

Marshak, D. 1996. The emotional experience of school change: resistance, loss, and grief. NASSP Bulletin 80 (577): 72-78.

Mauthner, M., M. Birch, J. Jessop and T. Miller. (Eds.). 2002. Ethics in qualitative research. Sage Publications.

Mauthner, S. N. and A. Doucet. 2003. Reflexive accounts and accounts of reflexivity in qualitative data analysis. Sociology 37 (3): 413-431.

McLaughlin, C. 2003. The feeling of finding out: the role of emotions in research. Educational Action Research 11 (1): 65-79.

Owen, D. 1996. Men, emotions and the research process: the role of interviews in sensitive areas. In Qualitative research: the emotional dimension, eds. K. Carter and S. Delamont, 56-67. Avebury, Ashgate Publishing Limited.

Peshkin, A. 1984. Odd man out: The participant observer in an absolutist setting. Sociology of Education 57:254-264.

- 1988. Virtuous subjectivity: In the participant-observer's I's. In The self in social inquiry, eds. D. N. Berg and K. K. Smith, 267-281. Sage Publications.

Rager, B. K. 2005. Self care and the qualitative researcher: when collecting data can break your heart. Educational Researcher May 2005. Available at: http://www.aera.net/uploadedFiles/ Publications/Journals/Educational_Researcher/3404/3404\%20Rager\%20PDF.pdf.

Reason, P. and J. Marshall. 1987. Research as personal process. In Appreciating adult learning: from the learner's perspectives, eds. D. Baid and V. Griffins. Kogan Page Publishers.

Ribbens, J. and R. Edwards. 1998. (Eds.). Feminist dilemmas in qualitative research. Sage Publication.

Silverman, D. 2005. Doing qualitative research: a practical handbook. Second edition. Sage Publications.

Solomon, R. C. 2003. What is an emotion? Classic and contemporary readings. Second edition. Oxford University Press. 
Sutton, R. I. and S. J. Schurman. 1988. On studying emotional hot topics: lessons from an investigation of organisational death. In The self in social inquiry, eds. D. N. Berg and K. K. Smith, 333-349. Sage Publications.

Van Maanen, J., P. K. Manning and M. L. Miller. 1993. Editors' introduction. In Emotions and fieldwork, eds. S. Kleinman and M. A. Copp, vii-viii. Sage publications.

Wilkins, R. 1993. Taking it personally: a note on emotion and autobiography. Sociology 27 (1): 93-100.

Williamson, H. 1996. Systematic or sentimental? The place of feelings in social research. In Qualitative research: The emotional dimension, eds. K. Carter and S. Delamont, 28-41. Avebury, Ashgate Publishing Limited.

Wincup, E. 2001. Feminist research with women awaiting trial: the effects on participants in the qualitative research process. In The emotional nature of qualitative research, ed. $\mathrm{K} . \mathrm{R}$. Gilbert, 17-35. CRC Press.

Young, E. H. and R. M. Lee. 1996. Fieldworker feelings as data: 'emotion work' and 'feeling rules' in first person accounts of sociological fieldwork. In Health and the sociology of emotions, eds. V. James and J. Gabe, 97-113. Blackwell Publishers. 